reflect a greater awareness of the "benefits" of aspirin among older physicians, a higher incidence of aches and pains and coronary risk factors with advancing age or the urge to prevent "impending" ischemic cardiac event!

This survey was conducted before publication of the Physicians Health Study in the United States ${ }^{6}$ or the British Male Physicians trial in the United Kingdom.? Thus, our results probably were not influenced by publication of these reports and subsequent media coverage of the "benefits" of aspirin. A major limitation of this survey, however, is relatively small number of participants. Another limitation of this survey is that most repondents were from the Northeast United States and, therefore, whether these data represent attitudes of most US physicians cannot be ascertained. However, the striking increase in aspirin intake with increase in age provides a basis to conduct larger surveys to assess physicians' attitudes toward novel therapy.

Lastly, intake of a relativcly small dose of aspirin suggests awareness among physicians that $325 \mathrm{mg}$ may be adequate to prevent coronary events, ${ }^{1}$ possibly by differentially inhibiting platelet function. ${ }^{5}$

1. Cairns JA, Clinical trials of antiplatelet during therapy in acute myocardial infarction, unstable angina, and aortocoronary bypass surgery. In: Mehta JL, ed Thrombosis and Platelets in Myocardial Ischemia. Philadelphia: F.A. Davis, 1987:231-246.

2. ISIS-2 (Second International Study of Infarct Survival) Collaborative Group Randomised trial of intravenous streptokinase, oral aspirin, both, or neither among 17,187 cases of suspected acute myocardial infarction. Lancet 1988;2:349 360 .

3. Steering Committee of the Physicians' Health Study Research Group. Preliminary report: findings from the aspirin component of the ongoing physicians' health study. $N$ Engl J Med 1988;318:262-264.

4. Peto R, Gray R, Collins R, Wheatley K, Hennekens C, Jamrozik K, Warlow C Hatner B, Thompson E, Norton S, Gilliland J, Doll R, Randomised trial of prophylactic daily aspirin in British male doctors. $\mathrm{Br}$ Med J 1988;296:313-316. 5. Weksler BB, Pett SB, Alonso D, Richter RC, Stelzer P, Subramanian V, TackGoldman K, Gay WA Jr. Differential inhibition by aspirin of vascular and platelet prostaglandin synthesis in atherosclerotic patients. $N$ Engl J Med 1983;308:800 805

6. The Steering Committee of the Physicians' Health Study Research Group Preliminary report: Findings from the aspirin component of the ongoing physician's health study. $N$ Engl $J$ Med 1988;318:262-264.

7. Peto R, Gray R, Collins R, Wheatiey K, Hennekens C, Jamrozik K, Warlow C, Mafner B, Thompson E, Norton S, Gilliland J, Doll R. Randomized trial of prophylactic daily aspirin in British male doctors. $\mathrm{Br}$ Med J 1988;296:313-316.

\title{
Pulmonary Extraction of Immunoreactive Atrial Natriuretic Factor in Dogs
}

Eric R. Bates, MD, Mark J. McGillem, BS, G. B. John Mancini, MD, and Roger J. Grekin, MD

A trial natriuretic factor (ANF) is a hormone predominantly secreted by the cardiac atria. It stimulates the kidney to produce natriuresis and diuresis, and vasodilates vascular smooth muscle. The half-life of the hormone is a few minutes, suggesting that breakdown occurs in many tissues. ${ }^{\prime}$ Significant extraction of ANF has been demonstrated across the capillary beds of liver, kidney and limb. ${ }^{1-3}$ Pulmonary extraction of the hormone has not been shown in $\operatorname{dogs}^{3}$ or man, ${ }^{1,2}$ however, even though rat lung homogenates destroy $\mathrm{ANF}^{4}$ and isolated rabbit lungs remove ANF, ${ }^{5}$ perhaps because blood samples in the in vivo studies were obtained from systemic arteries instead of pulmonary veins. If ANF is released into the left atrial cavity through the thebesian veins, systemic arterial sampling could underestimate pulmonary extraction of ANF. The purpose of this study was to determine whether ANF is extracted across the canine pulmonary perfusion bed.

Surgical exposure of the heart and femoral vessels was accomplished in 15 mongrel dogs. Blood samples were withdrawn from catheters in the fernoral vein, pulmonary artery, pulmonary artery wedge, pulmonary vein, left atrium, aorta and coronary sinus. Levels of immunoreactive $A N F$ (IR-ANF) were measured by radioimmunoassay after extraction with Sep-Pak car-

From the Division of Cardiology, Department of Internal Medicine, Veterans Administration Medical Center, and the University of Michigan Medical School, Ann Arbor, Michigan. This study was supported in part by funds from the Veterans Administration, Washington, DC, the American Heart Association of Michigan, Lathrup Village, Michigan, and the Amcrican Hcart Association, Dallas, Tcxas. Manuscript rcceived August 8, 1988; revised manuscript received October 9, 1988 , and accepted October 11 . tridges (Waters Associates). Antibody was obtained from Peninsula Laboratories, Inc. ${ }^{6}$

Results are listed in Table I. IR-ANF levels significantly increased from the femoral vein to the pulmonary artery. Levels were significantly decreased in the pulmonary artery wedge position and the pulmonary vein, compared with the pulmonary artery. There was a significant step up in the left atrium, compared with the pulmonary vein and the pulmonary artery wedge. Left atrial and aortic levels were not statistically different. Coronary sinus levels were 3 times higher than systemic levels.

Although 2 human studies 1,2 reported equivalent ANF levels in pulmonary arteries and systemic arteries, pulmonary wedge or pulmonary venous sampling was not performed and it was concluded that ANF was probably not extracted in the lung. Also, Wesselcouch et $\mathrm{al}^{3}$ found no extraction between right ventricular and left ventricular sampling sites in the dog. Rodeheffer et $\mathrm{al}^{7}$ reported a decrease in ANF levels in the capillary wedge position, compared with equivalent levels in the pulmonary artery and aorta. They suggested that the hormone was extracted by the lung and secreted from the left atrial endocardium, rather than attenuated by the sampling technique, because high ANF concentrations were found in left atrial tissue from a patient undergoing cardiac transplantation.

This study, using pulmonary venous sampling in the dog, demonstrates that $\Lambda \mathrm{NF}$ is partially extracted during pulmonary transit. The results confirm that samples obtained from the pulmonary wedge position accurately reflect pulmonary venous levels of IR-ANF. For unclear reasons, an amount of $\mathrm{ANF}$ approximately equivalent to 


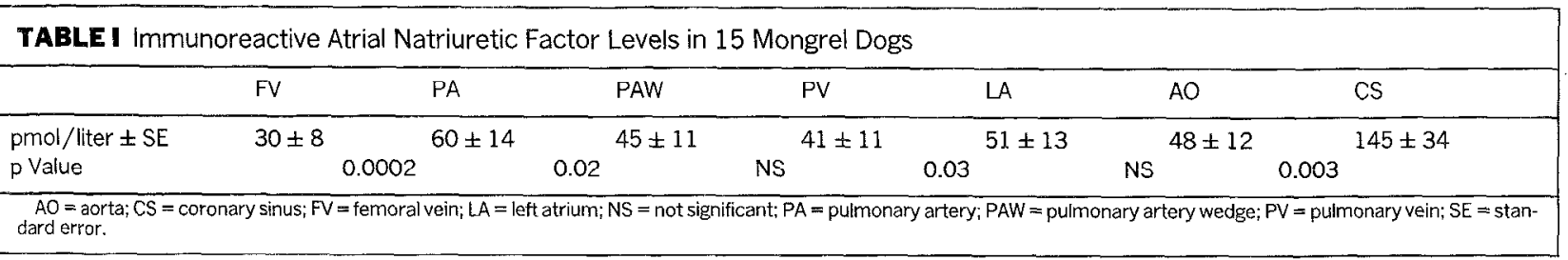

that extracted in the lung is released into the left atrial cavity, presumably through the thebesian veins in the left atrial endocardium, and restores systemic arterial levels to those found in the pulmonary artery.

These data suggest that the lung is an important site for ANF extraction. The decrease in plasma ANF across the lung (pulmonary artery to pulmonary vein) was 17.7 $\pm 4.1 \mathrm{pmol} /$ liter as compared with $17.3 \pm 4.9 \mathrm{pmol} /$ liter across the lower extremities (aorta to femoral vein). Because pulmonary blood flow is equal to systemic blood flow, these results suggest that a large proportion of ANF extraction occurs in the lung. It is possible that patients with pulmonary dysfunction have impairment of this extraction resulting in decreased clearance of the peptide. Such a mechanism could contribute importantly to the elevated ANF levels present in patients with congestive heart failure and pulmonary hypertension. ${ }^{6}$ Careful clearance studies will be requircd to ascertain the relative roles of increased secretion and decreased clearance of the peptide in these patients.

The lung may also be an important target organ for ANF. Large numbers of ANF receptors in the lung have been demonstrated using autoradiography. ${ }^{8}$ No evidence has been presented to date, however, as to whether these are clearance receptors (c receptors) or biologically active receptors (b receptors). Based on the high degree of clearance of ANF by the lung, it is likely that large numbers of the $c$ receptors are present. Some evidence has been presented to suggest that ANF has biologic effects on lung tissue. Large doses of the peptide have been reported to protect against chemical-induced pulmonary edema. ${ }^{9}$ ANF also dilates pulmonary arteries ${ }^{10}$ and has been shown to have bronchodilator properties. ${ }^{11}$

1. Crozier IG, Nicholls MG, Ikram H, Espiner EA, Yandle TG, Jans S. Atria natriuretic peptide in humans. Production and clearance by various tissues. $H y$ pertension 1986;8(suppl II):II-1I-II-15.

2. Schutten HJ, Henriksen JH, Warberg J. Organ extraction of atrial natriuretic peptide (ANP) in man. Significance of sampling site. Clin Physiol 1987,7:125 132.

3. Wesselcouch EO, Humphrey WR, Aiken JW. Effect of pulmonary and renal circulations on activity of atrial natriuretic factor. Am J Physiol 1985;249:R595 R602.

4. Tang J, Weber RJ, Chang D, Chang JK, Kiang J, Wei ET. Depressor and natriuretic activities of several atrial peptides. Regul Pept 1984,9:53-59.

5. Turrin M, Gillis CN. Removal of atrial natriuretic peptide by perfused rabbit lungs in situ. Biochem Biophys Res Commun 1986;140:868-873.

6. Bates ER, Shenker Y, Grekin RJ. The relationship between plasma levels of immunoreactive atrial natriuretic hormone and hemodynamic function in man. Circulation 1986;73:1155-1161.

7. Rodeheffer RJ, Tanaka I, Imada T, Hollister AS, Robertson D, Inagami T. Atrial pressure and secretion of atrial natriuretic factor into the human central circulation. JACC 1986,8:18-26.

8. Bianchi C, Gutkowski J, Thibault G, Garcia R, Genest J, Cantin M. Radioautographic localization of ${ }^{125} \mathrm{I}$-atrial natriuretic factor (ANF) in rat tissues. Histochemistry 1985,82:44I-452.

9. Imamura T, Ohnuma N, Iwasa F, Furuya M, Hayashi Y, Inomata N, Ishihara T, Noguchi T. Protective cffect of $\alpha$-human atrial natriuretic polypeptide ( $\alpha$ hANP) on chemical-induced pulmonary edema. Life Sci 1988;42:403-414.

10. Faison EP, Siegl PKS, Morgan G, Winquist RJ. Regional vasorelaxan selectivity of atrial natriuretic factor in isolated rabbit vessels. Life $S_{c i} 1985$. 37:1073-1079.

11. Hamel R, Ford-Hutchinson AW. Relaxant profile of synthetic atrial natriuretic factor on guinea-pig pulmonary tissues. Eur J Pharmacol 1986,121:151 155 